\title{
STUDIES ON THE GROWTH OF RHIZOCARPON GEOGRAPHICUM IN NW SCOTLAND, AND SOME IMPLICATIONS FOR LICHENOMETRY
}

\author{
BY \\ TOM BRADWELL \\ Murchison House, British Geological Survey, Edinburgh, UK.
}

Bradwell, T., 2010: Studies on the growth of Rhizocarpon geographicum in NW Scotland, and some implications for lichenometry. Geogr. Ann., 92A (X): xx-xx.

\begin{abstract}
Scotland, a maritime subpolar environment $\left(55-60^{\circ} \mathrm{N}\right)$, has seen relatively few applications of lichenometry - even though it offers much potential. Perhaps surprisingly, direct measurements of Rhizocarpon geographicum growth rates in Scotland are so far lacking. This study reports on the growth of this crustose areolate species from 2 sites in Assynt, NW Scotland, between 2002 and 2009. Repeat photography of 23 non-competing thalli growing under identical environmental conditions on a single vertical surface over 5 years at Inchnadamph showed growth rates to be a function of size - with larger thalli $(10-30 \mathrm{~mm})$ growing significantly faster than the smallest thalli $(<10 \mathrm{~mm})$. Mean diametral growth rates in thalli $>10 \mathrm{~mm}$ are $0.67 \mathrm{~mm} \mathrm{yr}^{-1}$ (s.d. $=0.16$ ). Studies on a second vertical surface near Lochinver, over 7 years, yielded complex growth data on a more mature population of $R$. geographicum thalli ( $<50 \mathrm{~mm}$ in diameter). Here, mean diametral growth rates in the larger thalli $(>10 \mathrm{~mm})$ are slower $\left(0.29 \mathrm{~mm} \mathrm{yr}^{-1}\right.$; s.d. $\left.=0.12\right)$ than those at Inchnadamph. However, at this site, competition with other species rules out any meaningful comparison of growth rates between the 2 sites. Other growth processes were monitored over the 5 to 7 -year study period, including hypothallus growth, areolae development, thallus coalescence, and inter-species competition - all have important implications for the use of Rhizocarpon species in lichenometry.
\end{abstract}

Key words: lichenometry, direct measurement, growth rate, Assynt

\section{Introduction}

Lichenometry is routinely used to derive the age of recent deposits and landforms in glacial and upland environments. Over the past 5 decades numerous lichenometric studies have been carried out in many areas of Europe to examine the timing of recent geomorphic events (e.g. Beschel 1956; Matthews 1974; Gob et al. 2004; Bradwell et al. 2006; Solomina et al. this volume). However, certain regions have seen only limited use of lichenometry. The British Isles, for example, has seen relatively few 
published lichenometric-dating or growth-rate studies (e.g. Innes 1983a,b; Winchester 1988; Macklin et al. 1992; Johnson and Warburton 2002; Winchester and Chaujar 2002). This is particularly surprising given that the large upland regions of Scotland, Ireland, England and Wales all offer particularly attractive, little-studied, locations for lichenometric dating of recent geomorphic events.

To the author's knowledge only one published study - Innes 1983a,b - has employed lichenometry quantitatively in Scotland. Furthermore, Innes (1983b) is the only author to derive lichenometric dating curves for Scotland (using gravestones in over 100 churchyards). Consequently, it would be fair to say that lichenometry has been underused in Highland Scotland - an environment where the technique offers much potential and could be central in solving many geomorphological questions.

The role of lichen size on lichen growth rate in Rhizocarpon geographicum - a proxy for lichen growth history - has been investigated in detail by only a small number of field studies (see Bradwell and Armstrong 2007 for a review). Armstrong (1983, 2005), Haworth et al. (1986), Bradwell and Armstrong (2007), and Benedict (2008) all found a general decrease in lichen growth rate with increasing size, after an optimum diameter is surpassed ( 30-50 mm). In contrast, Matthews (1994) found no decrease in growth rate in even the largest thalli $(>100 \mathrm{~mm})$. All of these studies were based on sample sizes of $<100$ thalli. Interestingly, a study of over 12,000 thalli (Trenbirth and Matthews, this volume) has shown no clear evidence of growth rate decline in large (older) thalli $(>50 \mathrm{~mm})$, but does indicate that size plays a role in determining long-term growth rates in Rhizocarpon subgenus Rhizocarpon. These new results serve to underline the uncertainty still surrounding the growth curve of $R$. geographicum - in turn, this has important implications for the use of crustose areolate lichens in dating studies (Bradwell 2009; Armstrong and Bradwell, this volume; Trenbirth and Matthews, this volume).

\section{Aims}

The original aims of this study, established in 2002, were simple:

- To determine the average growth rate of Rhizocarpon geographicum in NW Scotland, by direct measurement over a 5-year period. 
However, by the second measurement period (2004) it became apparent that growth rates were slower than expected and competition between thalli was likely to detrimentally affect lichen growth rates. Hence, it was decided to extend the study to a second site in the same region and also extend the timeframe of the study. In 2004 the aims of the study were revised to include an investigation of the role of lichen size on lichen growth rate, in a controlled micro-environment. A secondary aim of this longterm study was to monitor and record other biological processes in $R$. geographicum thalli, such as the nature of marginal growth, thallus coalescence, decay and interspecies competition. Some preliminary results of these findings are also presented in this paper.

\section{Site descriptions}

Several potential sites in NW Scotland were examined in 2001-02 and their suitability for a long-term lichen-monitoring study was assessed. Alltanabradhan Mill, a late $18^{\text {th }}$-century ruined meal mill, $5 \mathrm{~km}$ north of Lochinver, in Assynt, was chosen because it possesses a number of large (mature) yellow-green Rhizocarpon thalli on unpolished vertical stone surfaces (Fig. 1, Fig. 2A). Other reasons for choosing this study site are its present isolation from human habitation $(>1 \mathrm{~km})$ and hence lack of disturbance; its long-term stability (>200 years); and yet its relative ease of access (500 $\mathrm{m}$ from a road). One west-facing granite-gneiss block within the east wall of the mill was particularly attractive for study as it possessed 15 yellow-green Rhizocarpon thalli, including 5 over $30 \mathrm{~mm}$ in diameter, which could all be captured in 1 close-up photograph (field of view $=$ ca. $30 \mathrm{~cm}$ ). Several lichens at this site were identified in the field with a handlens as Rhizocarpon geographicum (L.) DC., using the broadly circumscribed criteria of Purvis et al. (1992). However, not all thalli could be positively identified to species level, only to group level; hence they are referred to as 'section Rhizocarpon' thalli in this study, following the criteria of Poelt (1988). These 15 thalli were photographed and precisely measured, but not marked, in May 2002 (see Methods below).

A second site in the same region of NW Scotland, at Inchnadamph, $30 \mathrm{~km}$ to the west (Fig. 1, Fig. 2B), was chosen in 2004 for a number of reasons: 1) The study surface, a 
dressed but unpolished, vertical orthoclase-granite headstone in the graveyard at Inchnadamph Kirk (church) possesses numerous (>30) non-competing yellow-green Rhizocarpon thalli. 2) The stone surface is west-facing as at Alltanabradhan Mill. 3) The stone surface is smooth at a sub-mm level, which would facilitate precise $(<0.1$ $\mathrm{mm}$ ) measurement of lichen growth. 4) The surface has a known maximum age (AD 1840, inscribed on the headstone). 5) The surface has long-term stability (>150 years) and is likely to remain undisturbed in the future. Finally, 6) the site at Inchadamph receives, on average, almost twice as much rainfall than the coastal site near Lochinver, (2200 mm/year cf. 1200 mm/year; Figure 1) and it was hoped that this may result in more rapid, measurable growth over the 5-year study period. Numerous yellow-green Rhizocarpon lichens at this site were identified in the field with a handlens as Rhizocarpon geographicum (L.) DC., using the broadly circumscribed criteria of Purvis et al. (1992). However, as at the first site, not all thalli, particularly the smallest, could be positively identified to species level; hence they are referred to collectively as 'Rhizocarpon section Rhizocarpon' thalli. The granite headstone and all thalli were photographed and precisely measured, but not marked, in May 2004 (see Methods below). The two sites, Alltanabradhan Mill and Inchnadamph Kirk, were revisited every year, normally in May, between 2004 and 2009, when the study lichens were re-photographed, but not always re-measured in the field.

\section{Methods}

Photographs were taken of lichens with scale bars at Alltanabradhan Mill and Inchnadamph Kirk using a Canon EOS 350 digital SLR camera kept perfectly horizontal using a fixed spirit level. These high-resolution (8 MegaPixel) digital images were measured on screen to obtain precise lichen growth measurements. The measurement method is similar to that adopted by Benedict (2008). The images were enlarged 1200\% in Adobe Photoshop 8.0 and accurately overlaid, using the scale bars to determine precise size and using numerous natural identification marks as consistent spatial reference points (Figure 3). Minor ortho-rectifications were made for geometric distortion using the method outlined by Locke et al. (1979). Although photographs of the thalli were taken in every year, this study is principally concerned with average growth rates over a multi-annual (5 to 7-year) period, hence inter-annual growth measurements are not reported here. Digital tracings of the thallus margin at 
1200\% enlargement, using a $0.1 \mathrm{~mm}$ line thickness, in 2002/2004 and 2009 allowed lichen growth to be fully visualised and quantified at exactly the same scale. Onscreen diameter measurements of each thallus were taken along the maximum vertical axis (termed 'north-south') and maximum horizontal axis ('east-west'), irrespective of the thallus long axis (Fig. 3). This avoids any potential confusion or inaccuracies arising from measurement inconsistency. The on-screen measurements were made using the measurement tool in Adobe Photoshop, accurate to $0.01 \mathrm{~mm}$. However, given the uncertainty surrounding successful identification of the hypothallus margin on black surfaces, and the errors in the photogrammetric technique, measurement precision is, in reality, no more than $0.05 \mathrm{~mm}$ and average growth rates are expressed as such.

\section{Results}

\section{Growth rates}

50 yellow-green Rhizocarpon lichens (IK01-IK50) were identified and monitored on a single gravestone at Inchnadamph churchyard between May 2004 and May 2009 (Fig.4). In May 2004, 38 of these thalli were not coalescing or in direct competition with other thalli. By May 2009 only 23 remained as healthy, discrete, non-competing thalli. The average diametral growth rate (DGR) of these 23 individual thalli has been calculated for the whole 5-yr period (i.e. total diameter increase divided by 60

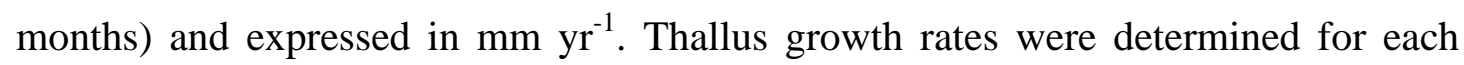
diameter (N-S and E-W) over the 5-yr period and then averaged. The average growth rate of each lichen thallus has been plotted against its respective average diameter (in May 2004 at the start of the study), with the accompanying error bars representing the variance between minimum and maximum growth rate (Fig. 5). The resultant graph shows mean DGR between non-competing thalli varies from $<0.10 \mathrm{~mm}$ to $0.90 \mathrm{~mm}$ $\mathrm{yr}^{-1}$. The overall mean DGR of the 17 thalli $>10 \mathrm{~mm}$ is $0.67 \mathrm{~mm} \mathrm{yr}^{-1}$. The standard deviation of this dataset is 0.16. Most striking is the distinct relationship between thallus size and DGR in Rhizocarpon section Rhizocarpon, with growth being slowest in the smallest thalli $(<10 \mathrm{~mm})$. Larger thalli $(>10 \mathrm{~mm})$ grew considerably faster ( $\sim 0.6-1.0 \mathrm{~mm} \mathrm{yr}^{-1} \mathrm{cf} .<0.4 \mathrm{~mm} \mathrm{yr}^{-1}$ ) over the 5-year period than smaller thalli of the same species on the same surface. No evidence of the declining growth phase observed by others (e.g. Armstrong 1983; Bradwell and Armstrong 2007) - was identified in this study, as no large thalli (>50 mm) were included. The relationship 
between growth rate and thallus size identified $n$ this study is best described by an logarithmic function: $\mathrm{y}=0.312 \ln (\mathrm{x})-0.2189\left(\mathrm{r}^{2}=0.74\right)$; the optimum linear regression produces a poorer fit with notably larger residuals $\left(y=0.03 x+0.1168 ; r^{2}=\right.$ 0.66) (Fig. 5). The logarithmic relationship between thallus size and growth rate indicates that growth rates increase with size but in an asymptotically decreasing way, up to at least a maximum diameter of $30 \mathrm{~mm}$. The relationship between growth rate and thallus size in $R$. geographicum is often used as a proxy for thallus growth rate over time (e.g. Matthews 1994; Karlén and Black 2002; Benedict 2008). However, the small size and truncated nature of the present dataset precludes making any definitive statements on the true shape of the age-size curve. Other studies which include larger (>40 mm) non-competing thalli (Bradwell and Armstrong 2007), have shown the agesize relationship to be best described by a second-order polynomial or parabolic curve, with highest growth rates occurring in thalli between $\sim 10 \mathrm{~mm}$ and $\sim 50 \mathrm{~mm}$, and below-optimum growth occurring in larger $(>50 \mathrm{~mm})$ thalli. It is possible that the curvilinear, asymptotic, relationship identified in this study represents only one limb of a broad parabolic curve, of the type identified by Bradwell and Armstrong (2007) (Fig. 5).

15 yellow-green lichens were identified and monitored on a single stone surface at Alltanabradhan Mill between May 2002 and May 2009. Average growth rates varied considerably between thalli over this time: ranging from -0.12 to $+0.45 \mathrm{~mm} \mathrm{yr}^{-1}$. However, 12 of the 15 thalli were seen to be in competition with other crustose thalli during the monitoring period. Competition adversely affects growth rates (Armstrong, 2002), even resulting in thalli decreasing in size (see below). Hence, the results from Alltnabradhan Mill, although interesting, cannot be directly compared with those of non-competing thalli at the wetter site of Inchnadamph, $20 \mathrm{~km}$ to the east. The overall mean DGR of the dataset (excluding those $<10 \mathrm{~mm}$ and those displaying negative growth) is $0.29 \mathrm{~mm} \mathrm{yr}^{-1}$, with a standard deviation of 0.12 .

\section{Additional observations on lichen growth over the measurement period}

Apothecia

Apothecia - the small reproductive structures within the fungal component of crustose lichens - were observed only in thalli $>10 \mathrm{~mm}$ in diameter. Where present, apothecia 
are seen only to occur within the central portion of $R$. geographicum thalli. A marginal apothecia-free zone occurs in all studied thalli at both sites. This zone varies in width depending on the diameter of the thallus, but in larger thalli ( $>30 \mathrm{~mm}$ ) with established apothecia, it is typically between $4-6 \mathrm{~mm}$ wide (Fig. 6); the same phenomenon was reported by Benedict (2008) in Rhizocarpon superficiale thalli in Colorado. Sequential photographs between 2002 and 2009 (this study) showed permanence and stability of apothecia within the central portions of thalli (Fig. 6). With new apothecia generally, but not exclusively, appearing towards the outer part of thalli. Enlargement of apothecia was slow and barely measurable $(<0.1 \mathrm{~mm})$ over the entire 7-year period.

\section{Marginal growth}

Growth at the margin of several mature thalli was studied using close-up photography taken every year between 2002 and 2009 at Alltanabradhan Mill. Repeat observations demonstrate that the marginal growth of $R$. geographicum takes place initially by the advance of the fungal hypothallus across the substrate, followed by the appearance of tiny algal areolae within the fungal margin (Fig. 6), as described by others (Benedict 1990, 2008; Armstrong and Smith 1996; Armstrong and Bradwell 2001). The time elapsed between hypothallus advance and the 'birth' of new areolae in this outer rim, may be as much as 3-4 years in some instances at this site. Furthermore, marginal growth of thalli may be checked by moisture availability. Hypothallus growth of ABM03 between May 2002 and 2004, a period with below average rainfall, was very restricted $(<0.5 \mathrm{~mm})$ with the appearance of very few new areolae during this time (Fig. 6). By comparison, between 2006 and 2008, when annual rainfall totals were in excess of the 30-year average, marginal areolae 'birth' and enlargement was more common and more rapid. The inter-annual marginal growth variability observed in this study is interesting, and echoes the findings of detailed studies by Armstrong (2006). Such findings may have important implications for lichenometric-dating studies which derive, and often extrapolate, average growth rates over long periods of time. Clearly, more measurements are required of marginal growth rate variability from a range of environmental settings before any firm conclusions can be made. 


\section{Coalescence}

Few lichenometric studies take account of thallus coalescence. This small-scale monitoring study in NW Scotland observed several coalescent and inter-growing thalli over 5 years or more (Fig. 7). Measurements of these thalli were not included in conventional growth-rate calculations at either site. The process of intergrowth between two competing thalli of the same species is complex and worthy of more detailed study. However, it is sufficient to note here that when two thalli coalesce (such as IK27 \& IK28), their margins fuse and the suture zone can be delimited by the black hypothallus free of areloae (Fig. 7). Over time, however, this zone can become less distinct as algal areolae colonise the fungal mat. Repeat photography of coalescent thalli IK27 \& IK28 shows that in addition to marginal growth continuing, areolae growth within the suture zone also occurs (Fig. 7). The end result being that, after a number of years (perhaps as few as 10), no physical expression of the coalescent margin may be visible. This has implications for lichenometric-dating studies, which often seek to identify the largest (and perceived oldest) individual within a given population. The chance of mistaking 2 or more coalescent areolate thalli as a single thallus may be greater than currently perceived.

\section{Competition}

Competition between lichens can take several forms (crustose vs crustose; foliose vs crustose; foliose vs foliose, etc.). At both sites inter- and intra-species competition has affected the yellow-green Rhizocarpons being studied (Fig. 8). So much so that at Inchnadamph numerous thalli could not be included in the growth rate study over the entire 5-year period owing to competition with other thalli. At Alltannabradhan Mill competition affected all but 5 of the 15 thalli monitored over the 7 year study. Competition between $R$. section Rhizocarpon thalli ABM04, 05 and 06 has resulted in a truce (i.e. zero growth in 7 years) along their competing margins (Fig. 8). A truce may also result where inter-species competition occurs (Armstrong 2002). Direct competition between ABM04, 05, 06 and two large $R$. reductum thalli in this study has resulted in overgrowth of the $R$. geographicum thalli by the $R$. reductum thalli (Fig. 8). A maximum overgrowth distance of $0.85 \mathrm{~mm}$ was measured between 2002 and 2009. This phenomenon has resulted in an overall decrease in thallus size of ABM04 and ABM05 over the 7-year study period, and consequently a negative average growth rate. 
Competition between foliose thalli (e.g. Parmelia spp.) has been reported by previous workers in an attempt to gauge the relative competitive strength between species (Pentecost 1981; Armstrong 1986). However, the competition for space between foliose and crustose species is less well studied. This subject clearly warrants more detailed investigation, but it is important to note the following findings from the monitoring study at Inchnadamph. Firstly, that foliose species, such as Parmelia spp. commonly compete to occupy the same space as crustose lichens. Secondly, that these foliose species have considerably faster radial growth rates than crustose species, typically 1-3 mm per year (Fig. 8), but may live for several decades. Thirdly, they have superior competitive strength over crustose species, which they can overgrow with ease (e.g. IK18, IK23, IK40). It remains to be seen what the affect of overgrowth by Parmelia spp. is on Rhizocarpon spp. - something which a future study will seek to investigate. However, judging by the relatively clean, lichen-free, surfaces exposed beneath the spalled Parmelia thalli (Figs. 2 \& 7), it seems likely that once overwhelmed, thalli do not reappear intact or in good health.

\section{Degeneration and Mortality}

No thalli were seen to die within the course of the study at either site, although the health status of those overgrown by other (foliose) thalli was not determined (see above).

\section{Discussion}

Direct measurements of lichen growth in Scotland are conspicuously absent from the literature. Although lichenometry has considerable potential as a dating technique, particularly in the Scottish Highlands, few attempts have been made to determine the growth rates of the most commonly used lichen species, Rhizocarpon geographicum. This small study demonstrates that measurable growth in even slow-growing lichen species in NW Scotland, such as those within the Rhizocarpon group, can be detected in only 1 or 2 years. However, at least several years (3-7) of observations are recommended to determine average growth rates and to smooth out any seasonal or inter-annual growth variability (Armstrong 2006; Trenbirth and Matthews, this volume). 
Rhizocarpon section Rhizocarpon growth rates in this study are size related, as found in other studies. However, controversy still surrounds the exact shape of the growth rate curve. Smaller growth rate studies, typically involving $<100$ thalli in close proximity under very similar micro-environmental conditions, tend to produce similar results - with growth describing a broadly asymmetric parabolic curve (e.g. Armstrong 2005; Bradwell and Armstrong 2007). By contrast, larger studies, involving many thalli growing on a range of surfaces, show no clear trends (Matthews 1994; Trenbirth and Matthews, this volume). Although puzzling, this apparent paradox may result from the high degree of scatter or statistical 'noise' inherent within large biological datasets (>1000 measurements). Perhaps importantly, the present study examines the growth of 23 thalli living on a single vertical surface exposed to the same environmental conditions. Any growth-size relationship should therefore be a factor of internal biological processes alone rather than the result of numerous external (environmental) factors.

Average long-term growth rates of $R$. geographicm lichens in this study ( 0.7 $\mathrm{mm} \mathrm{yr}^{-}$ 1; at Inchnadamph), compare well with those from other studies in similar climatic settings. Bradwell and Armstrong (2007) reported mean diametral growth rates (averaged over 4.33 years) of between 0.6-1.0 $\mathrm{mm} \mathrm{yr}^{-1}$ (thalli $>10 \mathrm{~mm}$ diameter) in maritime southern Iceland. Armstrong's (1983, 2005) detailed studies recorded mean

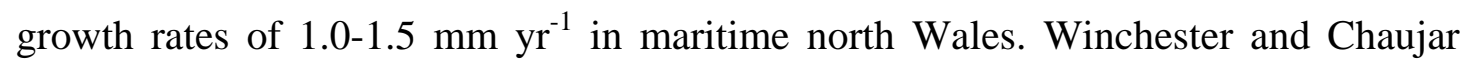
(2002) found similar, but slightly faster $\left(\sim 1.6 \mathrm{~mm} \mathrm{yr}^{-1}\right)$ growth rates in Capel Curig, North Wales - a site experiencing exceptionally high rainfall. Matthews (1994) reported mean diametral growth rates of $0.66 \mathrm{~mm} \mathrm{yr}^{-1}$ in southern Norway averaged over 5 years. This study has since been extended in time and scope (Trenbirth and Matthews, this volume). Admittedly from a small sample of only 5 studies, there is at least some correlation between measured growth rates and precipitation totals, as found by others in a brief synthesis of lichenometric studies (Sancho et al. 2007). These tentative findings tend to support those who have argued that long-term average growth rates are probably a function of climate, in particular year-round precipitation or the degree of 'oceanicity' (Beschel 1956; 1961; Benedict 1990; Bradwell 2001). Data from the present study gives a tantalising glimpse of this relationship at 2 sites experiencing different amounts of rainfall. But clearly, much patient and careful 
monitoring work of growth in non-competing lichen thalli is still needed before such a link can be made more definitively.

Perhaps of equal importance for lichenometry are long-term observations relating to other lichen growth processes. In Assynt, where lichen growth rates are relatively high, ongoing coalescence of two or more thalli can be monitored over a period of only 5 years. Repeat photography has shown that areolae continue to colonise the hypothallus around the margins and in the zone of coalescence, closing the physical gap between the two thalli and blurring their individual identities. Repeat monitoring of coalescent thalli over a period of many years (10 or more) is needed to completely document this intergrowth. But, in the meantime, this study has highlighted that care should be taken when including misshapen, not apparently coalescent, thalli in lichenometric surveys - especially when the long axis of a single thallus is used as the best measure of surface age.

Competition between thalli affects growth rates. This study has shown that where crustose thalli compete with other crustose species the growth rate of one or both is compromised. In certain cases, where different species compete for space, one species may overgrow the other. This has been observed at Alltanabradhan Mill between Rhizocarpon reductum and Rhizocarpon geographicum, and at Inchnadamph where fast-growing foliose lichens (Parmelia spp.) are actively overgrowing crustose microlichens, such as $R$. geographicum. It is not clear whether the slow-growing crustose species will survive this overgrowing process. However, the suggestion is that they will not. This competition for space has important implications for lichenometric studies, particularly those that seek to find the largest (assumed-to-be pioneer) crustose thalli as indicators of surface age. It is highly likely that, in maritime subpolar settings, even quite young surfaces ( $<100$ years) may be reaching climax communities. With an ever-decreasing amount of space for continued unchecked growth, it is hard to see how crustose lichen growth could continue undisturbed for an indefinite length of time. Under these scenarios, the usefulness of largest-lichen dating techniques may be severely limited. 


\section{Acknowledgements}

I thank Richard Armstrong for his continued enthusiasm and advice over the last 10 years, and Maarten Krabbendam (BGS Northwest Highlands Project) for funding aspects of this work. Chris Ellis (Royal Botanic Gardens Edinburgh) and Richard Tipping are thanked for their thorough reviews of the manuscript. Published with the permission of the Executive Director, BGS (NERC).

Dr Tom Bradwell, British Geological Survey, Murchison House, West Mains Road, Edinburgh, EH9 3LA, UK

Email:tbrad@bgs.ac.uk

\section{References}

Armstrong, R.A., 1983: Growth curve of the lichen Rhizocarpon geographicum. New Phytologist, 94: 619-622.

Armstrong, R.A., 1986: Competition between three lichen species using a factorial experimental design. New Phytologist, 104: 637-641.

Armstrong, R.A., 2002: The effect of rock surface aspect on growth, size structure and competition in the lichen Rhizocarpon geographicum. Environmental and Experimental Botany, 48: 187-194.

Armstrong, R.A., 2005: Growth curves of four crustose lichens. Symbiosis, 38: 45-57.

Armstrong, R.A., 2006: Seasonal growth of the crustose lichen Rhizocarpon geographicum (L.) DC. in south Gwynedd, Wales. Symbiosis, 41: 97-102.

Armstrong, R.A. and Bradwell, T., 2001: Variation in hypothallus width and the growth of the lichen Rhizocarpon geographicum (L.) DC. Symbiosis, 30: 317-328.

Armstrong, R.A. and Bradwell, T., 2010: Growth of crustose lichens: a review. Geografiska Annaler, 92A: tba. 
Armstrong, R.A. and Smith, S.N., 1996: Experimental studies of hypothallus growth in the lichen Rhizocarpon geographicum. New Phytologist, 132: 123-126

Benedict, J.B., 1990: Experiments on lichen growth. I. Seasonal patterns and environmental controls. Arctic and Alpine Research, 22: 244-254.

Benedict, J.B., 2008: Experiments on lichen growth. III. The shape of the age-size curve. Arctic, Antarctic and Alpine Research, 40: 15-26.

Beschel, R.E., 1956: Lichenometrie im Gletschervorfeld. Jahrbuch des Vereins zum Schutze der Alpenpflanzen und Tiere, Munchen. 22: 164-185.

Beschel, R.E., 1961: Dating rock surfaces by lichen growth and its application to the glaciology and physiography (lichenometry). In Raasch G.O. (ed.), Geology of the Arctic, Toronto: University of Toronto Press, 1044-1062.

Bradwell, T., 2001: Glacier fluctuations, lichenometry and climatic change in Iceland. $\mathrm{PhD}$ Thesis, University of Edinburgh, 365 pp.

Bradwell, T., 2009: Lichenometric dating: a commentary, in the light of some recent statistical studies. Geografiska Annaler, 91A: 61-70.

Bradwell, T., Dugmore, D.J. and Sugden, D.E., 2006: The Little Ice Age glacier maximum in Iceland and the North Atlantic Oscillation: evidence from Lambatungnajökull, southeast Iceland. Boreas, 35: 61-80.

Bradwell, T. and Armstrong, R.A., 2007: Growth rates of Rhizocarpon geographicum lichens: a review with new data from Iceland. Journal of Quaternary Science, 22: 311-320.

Gob, F., Petit, F., Bravard, J., Ozer, A. and Gob, A., 2003: Lichenometric application to historical and subrecent dynamics and sediment transport of a Corsican stream (Figarella River-France). Quaternary Science Reviews, 22: 2111-2124. 
Haworth, L.A., Calkin, P.E. and Ellis, J.M., 1986: Direct measurement of lichen growth in the central Brooks Range, Alaska USA, and its application to lichenometric dating. Arctic and Alpine Research, 18: 289-296.

Innes, J.L., 1983a: Lichenometric dating of debris flow deposits in the Scottish Highlands. Earth Surface Processes and Landforms, 8: 579-588.

Innes, J.L., 1983b: Development of lichenometric dating curves for highland Scotland. Transactions Royal Society Edinburgh, 74: 23-32.

Johnson, R.M., Warburton, J., 2002: Flooding and geomorphic impacts in a mountain torrent: Raise Beck, central Lake District, England. Earth Surface Processes and Landforms, 27: 945-969.

Karlén W., Black J.L., 2002: Estimates of lichen-growth rate in northern Sweden. Geografiska Annaler, 84A: 225-232.

Locke, W.W., Andrews, J.T. and Webber, P.J., 1979: A manual for lichenometry. British Geomorphological Research Group, Technical Bulletin, 26: 1-47.

Macklin, M.G., Rumsby, B.T., Heap, T., 1992: Flood alluviation and entrenchment: Holocene valley floor development and transformation in the British Uplands. Geological Society of America Bulletin, 104: 631-643.

Matthews, J.A., 1974: Families of lichenometric dating curves from the Storbreen gletschervorfeld, Jotunheimen, Norway. Norsk Geografisk Tidsskrift, 28: 215-235.

Matthews, J.A., 1994: Lichenometric dating: A review with particular reference to 'Little Ice Age' moraines in southern Norway. In Beck, C. (ed.), Dating in Surface Context, Albuquerque, New Mexico Press, pp. 185-212.

Pentecost, A., 1981: Aspects of competition in saxicolous lichen communities. Lichenologist, 12: 135-144. 
Poelt, J., 1988: Rhizocarpon Ram. em. Th. Fr. subgen. Rhizocarpon in Europe. Arctic and Alpine Research, 20: 292-298.

Purvis, O.W., Coppins, B.J., Hawksworth, D.L., James, P.W. and Moore, D.M., 1992:

The Lichen Flora of Great Britain and Ireland. Natural History Museum Publications: London.

Sancho, L.G., Green, T.G.A., Pintado, A., 2007: Slowest to fastest: Extreme range in lichen growth rates supports their use as an indicator of climate change in Antarctica Flora, 202: 667-673.

Solomina, O., Ivanov, M. and Bradwell, T., 2010: Lichenometric dating of moraines in the Polar Urals. Geografiska Annaler, 92A: tba.

Trenbirth, H. and Matthews, J.A., 2010: Preliminary results of a 25-year lichen growth rate monitoring study in southern Norway. Geografiska Annaler, 92A: tba.

Winchester $V .$, 1988: An assessment of lichenometry as a method for dating recent stone movements in two stone circles in Cumbria and Oxfordshire. Botanical Journal of the Linnean Society, 96: 57-68.

Winchester, V. and Chaujar, R.K., 2002: Lichenometric dating of slope movements, Nant Ffrancon, North Wales. Geomorphology, 47: 61-74.

\section{Figure captions}

Figure 1: Location of study sites in Assynt, NW Scotland. Isohyets show average annual rainfall totals in mm (1971-2000) (metoffice.gov.uk). 
Figure 2: Detailed location of lichen monitoring sites: (1) Alltanabradhan Mill, set amongst Lewisian gneiss terrain, $20 \mathrm{~m}$ above sea level; (2) gravestone at Inchadamph Kirk, on limestone geology at head of Loch Assynt, $50 \mathrm{~m}$ above sea level.

Figure 3: Measurement parameters used in this study. Maximum vertical axis (N-S); and maximum horizontal axis (E-W) (from points marked by red arrows) measured on screen in Adobe Photoshop. This technique replaces the need to mark the substrate in the field. Average of both axes gives mean diameter. Average of repeat measurements over time (2002/04 and 2009) gives mean growth rate (for both axes).

Figure 4: Study Site 2 - Photograph of granitic gravestone (in 2009) with map of numbered $R$. section Rhizocarpon thalli (IK01-50) monitored between 2004-2009.

Figure 5: Graphs of directly measured growth rate in $R$. section Rhizocarpon thalli. (i) Inchnadamph Kirk: average diametral growth rate $\left(\mathrm{mm} \mathrm{yr}^{-1}\right.$ ) (over 5 years) plotted against mean thallus size (in 2004). Error bars show maximum and minimum values.

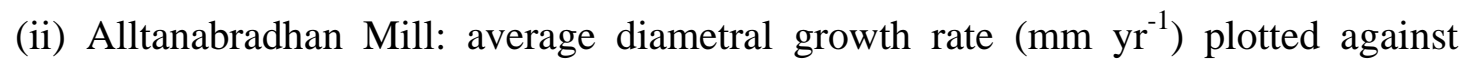
mean thallus size (in 2002). Error bars show maximum and minimum values. (top) Schematic graph of parabolic growth-rate curve (1), (type proposed by Bradwell and Armstrong, 2007), logarithmic best-fit (2), and linear best-fit (3) lines from this study are also shown for comparison.

Figure 6: Growth of Rhizocarpon section Rhizocarpon thalli at Alltanabradhan Mill between 2002 and 2009. Close-up photographs show the change in one mature thallus (ABM03) over the study period. Images are exactly the same scale. Bottom left panel: change in thallus outline over time, used to calculate average growth rate. Apothecia are also mapped to show their relative density and distribution. Note the marginal zone ( $\sim 5 \mathrm{~mm}$ wide) free of apothecia. Bottom right panel: sequential close-up photographs of growth at the SE margin of ABM03, highlighting the growth of the hypothallus relative to the development of new areolae.

Figure 7: Sequential photographs of coalescent R. geographicum thalli (IK21-22 and IK27-28) showing change in conjoined thallus morphology over a 5-year period 
(2004-2009). Note the development of new areolae within the 'suture zone'. Images are exactly the same scale.

Figure 8: Examples of competition between lichens at Inchnadamph Kirk: a truce between two R. geographicum thalli (ABM04 \& 05); overgrowth of $R$. geographicum by $R$. reductum thalli (red lines), measurable only after 5 years' monitoring. Overgrowth of crustose species by fast-growing foliose species (e.g. Parmelia spp.) can occur within a few years. Projected marginal outlines of Parmelia thalli (in 2014 and 2019) show that in 10 years' time the 3 non-competing $R$. section Rhizocarpon thalli in the centre of the image will probably have been overgrown. Images are exactly the same scale. 



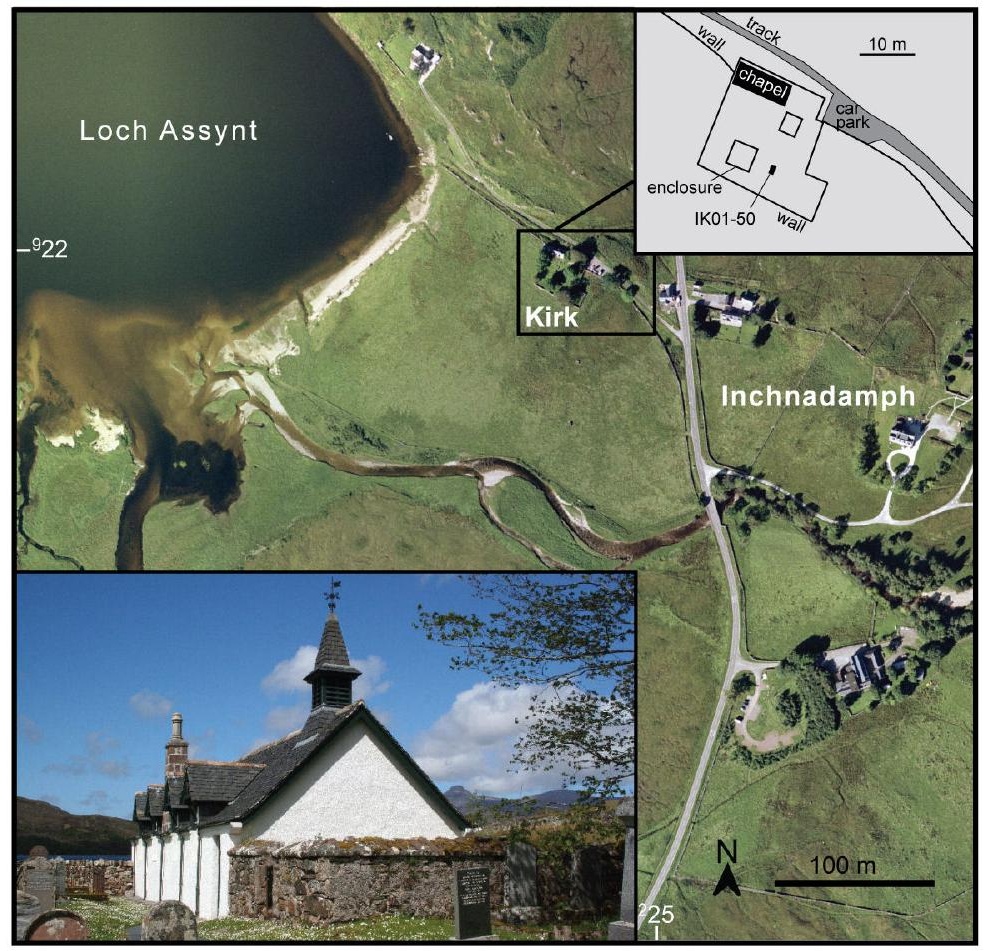




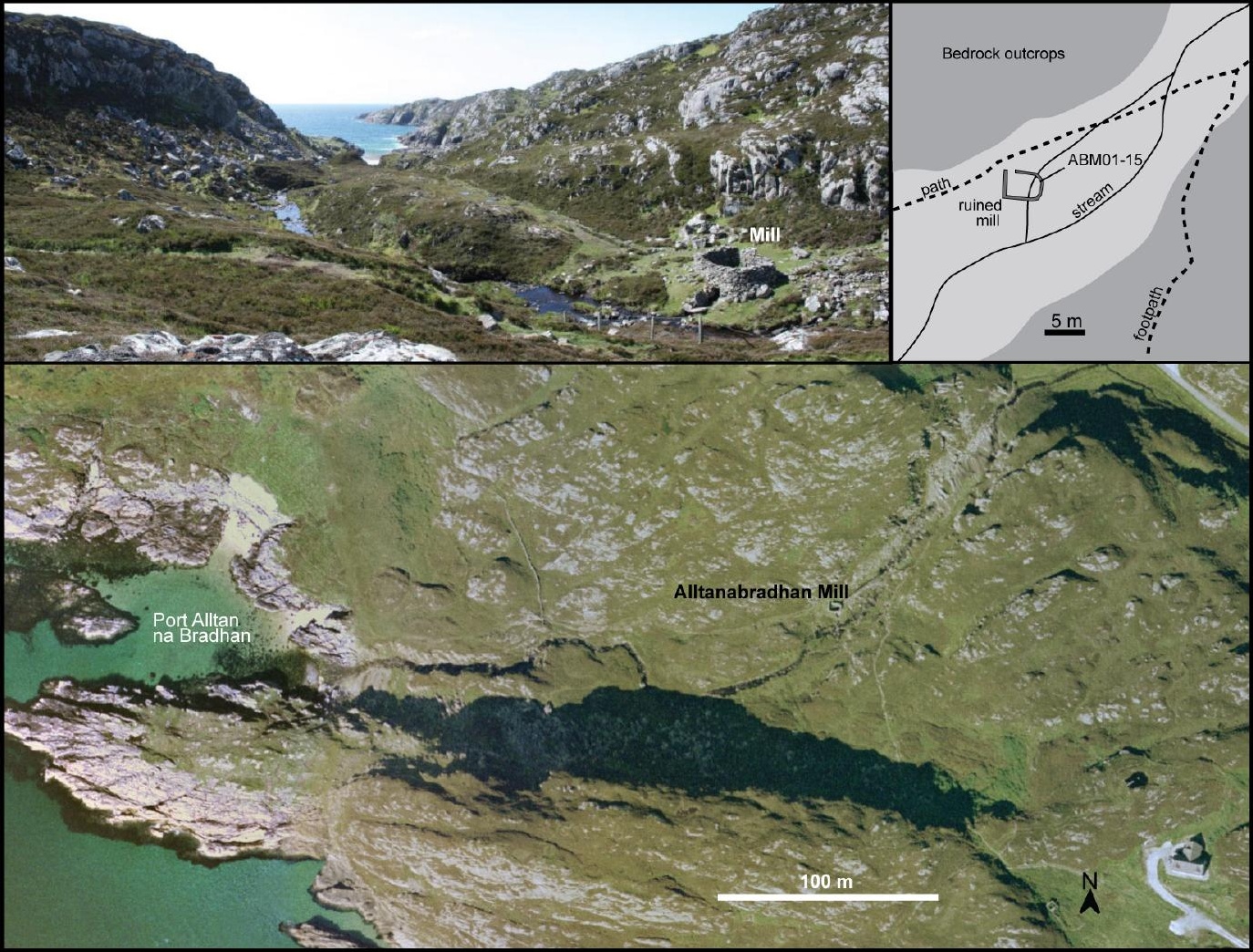




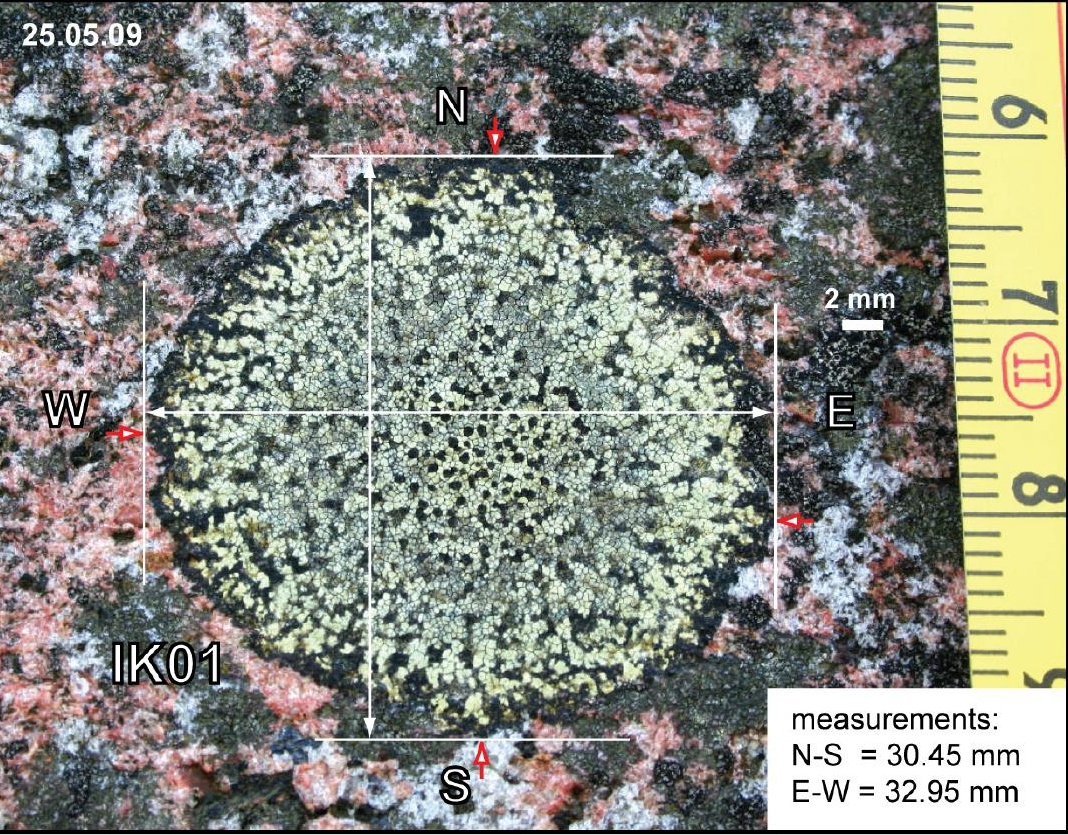



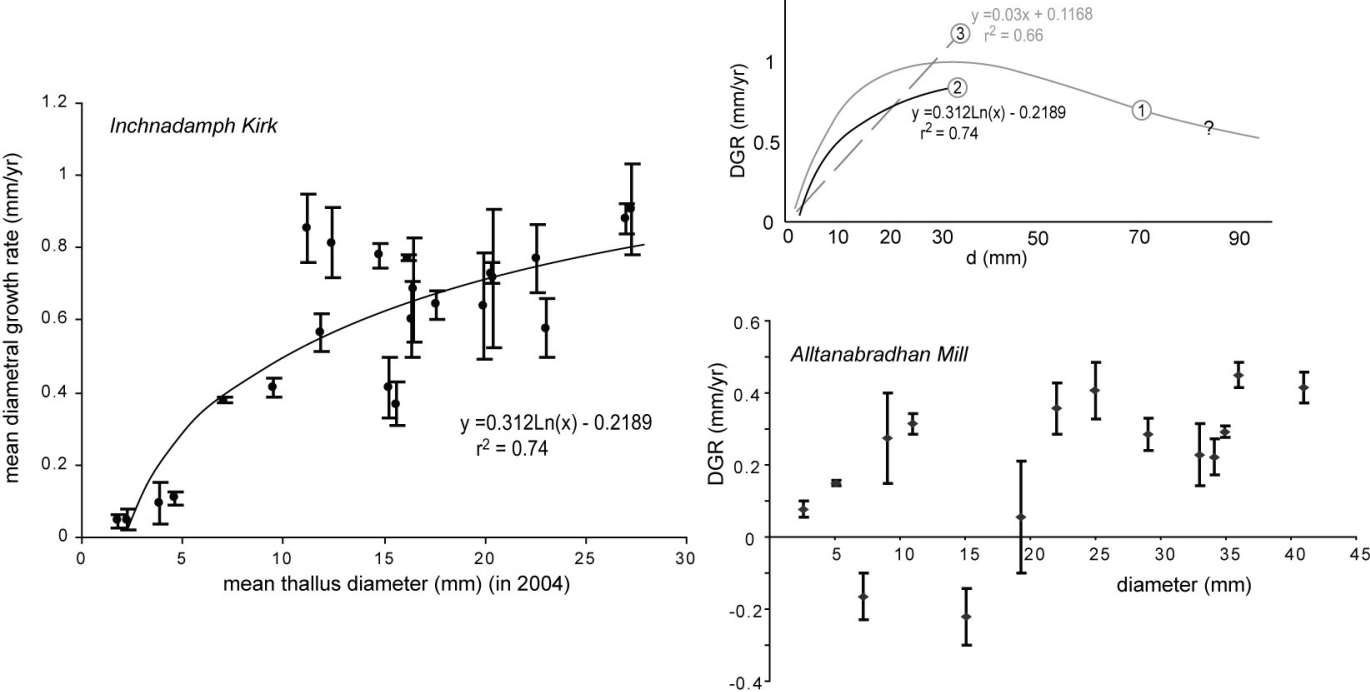


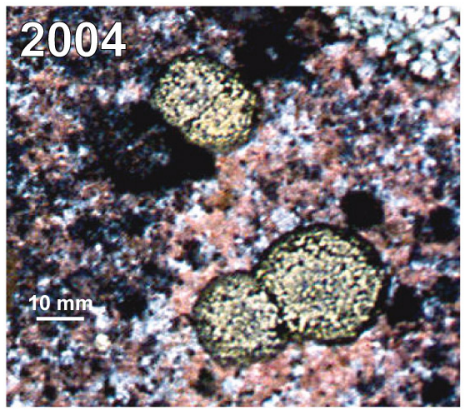

\section{Coalescence}

2009 . 1 . 5

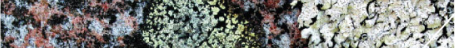

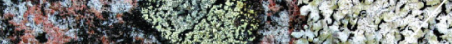

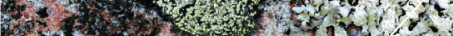

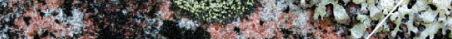

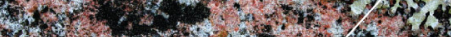

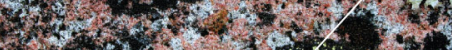

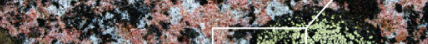

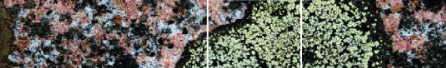

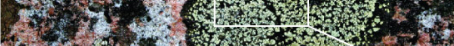

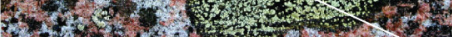

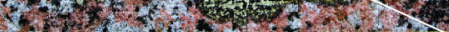

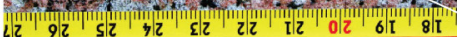

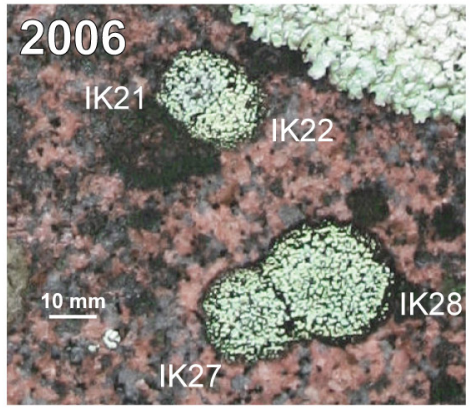

Close-up 3 . - $50-25$ 3. $\rightarrow x$

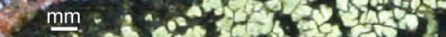

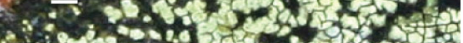

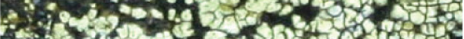

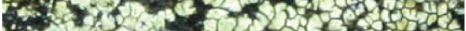

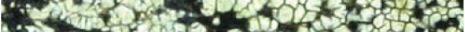

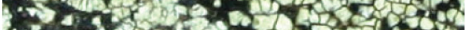

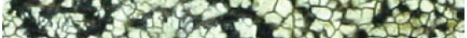

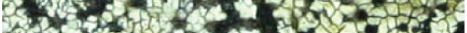

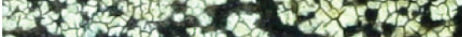

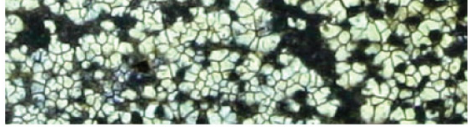


